\title{
THE ORGANIZATION'S INTERNAL ENVIRONMENT AND ITS IMPORTANCE IN THE ORGANIZATION'S DEVELOPMENT
}

\author{
Elisabeta-Emilia HALMAGHI*, Dumitru IANCU*, Marinela-Lidia BĂCILĂ** \\ * "Nicolae Bălcescu" Land Forces Academy, Sibiu, Romania \\ ** "Lucian Blaga" University, Sibiu, Romania \\ emmahalmaghi@gmail.com,dorin_dan@yahoo.com
}

\begin{abstract}
Analysis of an organization's internal environment, including the factors that influence the organization's activity: its owners, managers and leadership, employees, material resources, organizational culture, should determine the capabilities/capabilities/potential of the organization to adapt to/integrate to the external environmental components. In general, the characteristics and quality of an organization's internal environment allow the "exploitation" of the opportunities offered by the organization's external environment.
\end{abstract}

Keywords: internal environment, organization, organizational culture

\section{Introduction}

The organization, as a complex and dynamic socio-economic system, has an open character, being a component of the economy and society. Integration of the organization into the environment in which it operates shows that the organization is in an adequate relationship with the environment, but also that this relationship allows the manifestation of the internal dynamism of the organization.

The activity of an organization is the result of the ongoing interaction between the organization and its environment.

\section{The organization and its internal environment}

Being a complex and dynamic socioeconomic system, the organization is hard to define. This difficulty of definition "is determined both by the multitude of perspectives from which the organization is analyzed and by the evolution of organizational analysis which, depending on the theoretical and practical contributions brought over time, has devoted new ways of defining" [1] To highlight the different perspectives of the organization's approach, we will present some definitions to the organization:

G. Johns (1998): "Social invention designed to achieve common goals through group effort" [2]

M. Vlăsceanu (2003, 2005): "Are instruments for achieving a goal, respectively they have a set of specific and clear objectives, and their internal structure is designed to contribute to the achievement of the objectives" [3], [4];

E. Friedberg (1997, apud Stanciu, M.A. Ionescu, 2005): "Formalized and hierarchical human assemblies to ensure the cooperation and coordination of their members in order to achieve given goals" [5];

R.W. Scott (apud C. Neagu, M. Udrescu, 2008): "Collectivities oriented on the pursuit of relatively specific purposes and with highly formalized social structures" [6];

R.W. Scott (apud C. Neagu, M. Udrescu, 2008): "Systems of interdependent activities 
linking the changing coalitions of the participants" [7];

R.W. Scott (apud C. Neagu, M. Udrescu, 2008): "Communities whose participants pursue multiple interests, both different and common, but who recognize the importance of perpetuating the organization as an important resource" [8];

O. Nicolescu, I. Verboncu (2008): "A system usually composed of several people working on the basis of certain predetermined rules, in order to achieve a goal" [9];

D. Iacob, D.M. Cismaru, (2010): "Is a social system in which and through which people interact (cooperate) to achieve common goals" [10];

D. Iacob, D.M. Cismaru, (2010): "Social inventions aimed at achieving common goals through the convergent action of the group of people" [11];

E Burduş (2012): "The organization may be composed of two or more persons carrying out activities in order to achieve common objectives" [12].

The above definitions highlight some features of the organization [13], [14]:

a) the organization includes groups of people (members of the organization), structures and mission;

b) the organization involves a distinct form of correlation between both the members of the organization and the organization's goals, as well as between members of the organization and structures;

c) the organization is always specialized, has a mission that is represented by goals explicitly assumed by the members of the organization and socially recognized;

d) the organization ensures the coordination of the efforts of the members of the organization to achieve goals that individually would be very difficult to achieve or even impossible;

e) the organization cannot exist without an appropriate management that sets the objectives, ensure the procedural and organizational structural and organizational conditions necessary to achieve the objectives, as well as the coordination of the efforts of the members of the organization and their training and motivation;

f) the organization has a formal organizational structure, based on welldefined principles, rules and relations and unanimously accepted and respected by the members of the organization;

g) the organization is where its members spend most of their lives and can form a career;

h) The organization exercises on its members such an influence that they become "organizational".

For an organization, the environment is "an important variable that cannot be ignored in any way" [15] and includes "things, persons, conditions. For example, resources, constraints) or influences (cultural, political, legislative etc.) that interfere with its functioning" [16]

The environment of an organization is made up of two components: the external environment (environment) and the internal environment, characterized by specific elements and ways of acting within the organization.

\section{The importance of the internal environment in the development of the organization}

Regarding the composition of an organization's internal environment, there are several points of view in the literature. Each of these points of view emphasizes some elements, without excluding the others. Most of the works consider organizational culture to be synonymous with the internal environment of an organization. In our opinion, alongside organizational culture, an organization's internal environment also includes other elements within the organization: its owners, managers and leadership, employees, material resources.

Owners have a significant influence on the other components of the internal environment. This is because they are the 
ones who decide, directly or through representatives, on: the organization's main direction, profit distribution, development or abolition of the organization.

Managers, through their decisions and actions, influence both the organization's adaptation to the evolution and influences of the external environment as well as the actions and behavior of the employees in the organization.

Employees, through relationships that are established between them and the way they are determined to work to achieve the organization's goals, are the ones that determine the success or failure of the organization.

Organizational culture is commonly used to describe the internal environment of an organization because it is of particular importance in making the organization more efficient and has a long-term influence on it. The distinctive sign of solid organizational identity is the existence of a strong organizational culture.

In general, the organizational culture of an organization presupposes the existence of a "system of values, ideals, beliefs and common conduct rules that unite members of an organization" [17], [18].

Culture refers to it is found in every aspect of an organization. Each organization has its own ,set of beliefs, ideals, values and norms of conduct that are reflected in its structures, systems, and strategy approach." [19] These values, ideals, beliefs, Rules of conduct are not directly observable. The concrete manifestation of organizational culture is achieved through symbols, stories, rituals and ceremonies.

Organizational culture includes the organization's past and present, the current human resource in the organization, technology and physical resources, but also the goals, objectives and values of employees. Because each organization has a unique combination of the above elements, there will not be two organizations with the same organizational culture.

The culture of an organization determines [20]:
- organization's strategy;

- attitude towards groups outside the organization;

- the main criteria for the selection, evaluation and promotion of members of the organization;

- leadership style of managers, etc.

In order for the organization to achieve, in the long run, a high level of performance, the organizational culture must be at the same time [21]:

- strong - is accomplished through powerful managers who deliver all the core values. A consistent and well-defined system of values, alongside a performance manager, accepted by all members of the organization, leads in the long run to the organization's development.

- appropriate - in line with the strategy used by the organization;

- adaptable - flexible to changes in the external and internal environment. Organizations with adaptable culture, based on innovation, are successful organizations that can influence the competitive environment in their favor.

Strong organizational culture shows employees that the organization is unique, it has its own identity and contains a lot of symbolic elements that "come to be expressed through language, accounts, artifacts, behavior and other manifestations that relate to everyday life." [22]. Building a strong organizational culture does not mean abandoning individual cultural elements, but harmonizing values, beliefs, individual symbols with those promoted by the organization.

An organizational culture deeply rooted in the organization's identity can not be easily changed. That is why the impact that powerful organizational culture has on the efficiency of the organization may be positive or negative. The impact is positive when organizational culture is widespread among members of the organization; they accept it and help achieve the organization's goals. The negative impact occurs when 
organizational culture has a negative influence on the organization's goals.

\section{Conclusions}

$\square$ The organization, as an open system, is organically adaptive: changes in its structure and functioning are the result of transformations produced in its environment.

$\square$ Although the organization's external environment plays a key role in organizing the organization, organizational managers should pay appropriate attention to the internal environment, becoming more and more important than in the past.

$\square$ In order to describe the internal environment of an organization, organizational culture is frequently used as it has a high importance in streamlining the organization's work.

$\square$ For the organization to achieve a high performance in the long run, organizational culture must be strong, appropriate and adaptable at the same time.

\section{References}

[1] Emanoil Muscalu, Dumitru Iancu, Elisabeta-Emilia Halmaghi, The Influence of the External Environment on Organizations, Journal of Defences Resources Management, Vol. 7, Issue 2 (13), 2016, p. 134.

[2] Gary Johns, Comportament organizaţional. Înţelegerea şi conducerea oamenilor în procesul muncii, Editura Economică, Bucureşti, 1998, p. 4.

[3] Mihaela Vlăsceanu, Organizaţii şi comportament organizaţional, Editura Polirom, Iaşi, 2003, p. 51.

[4] Mihaela Vlăsceanu, Organizaţia: proiectare şi schimbare: introducere în comportamentul organizaţional, Editura Comunicare.ro, Bucureşti, 2005, p. 58.

[5] Ştefan Stanciu, Mihaela Alexandra Ionescu, Cultură şi comportament organizaţional, Editura Comunicare.ro, Bucureşti, 2005, p. 19.

[6] Cibela Neagu, Mircea Udrescu, Managementul organizaţiilor, Editura Tritonic, Bucureşti, 2008, p. 12.

[7] Idem.

[8] Idem.

[9] Ovidiu Nicolescu, Ion Verboncu, Fundamentele managementului organizaţiei, Editura Universitară, Bucureşti, 2008, p. 94.

[10] Dumitru Iacob, Diana-Maria Cismaru, Organizaţia inteligentă. Zece teme de managementul organizaţiilor, Editura Comunicare.ro, Bucureşti, 2013, p. 35.

[11] Dumitru Iacob, Diana-Maria Cismaru, op.cit., p. 41.

[12] Eugen Burduş, Tratat de management, ediţia a II-a, Editura Pro Universitaria, Bucureşti, 2012, p. 178.

[13] Dumitru Iacob, Diana-Maria Cismaru, op.cit., p. 41.

[14] Cibela Neagu, Mircea Udrescu, op.cit., pp. 12-14.

[15] Mihaela Vlăsceanu, Organizaţii şi comportament organizaţional, Editura Polirom, Iaşi, 2003, p. 139.

[16] Mihaela Vlăsceanu, Organizaţia: proiectare şi schimbare: introducere in comportamentul organizaţional, Editura Comunicare.ro, Bucureşti, 2005, p. 90.

[17] Cibela Neagu, Mircea Udrescu, op.cit., p. 35.[18] Ştefan Nedelea (coordinator), Managementul organizaţiei, Editura ASE, Bucureşti, 2008, p. 43.

[19] Cibela Neagu, Mircea Udrescu, op.cit., p. 36.

[20] Idem.

[21] Cibela Neagu, Mircea Udrescu, op.cit., p. 37.

[22] Idem. 